\title{
Social Environment of Special Needs in Inclusive Primary School: A Descriptive Research with Phenomenology Approach
}

\author{
Rizqi Fajar Pradipta \\ Special Education \\ Universitas Negeri Malang \\ Malang, Indonesia \\ rizqi.fajar.fip@um.ac.id
}

\author{
Umi Safiul Ummah \\ Special Education \\ Universitas Negeri Malang \\ Malang, Indonesia \\ umi.safiul.fip@um.ac.id
}

\author{
Dimas Arif Dewantoro \\ Special Education \\ Universitas Negeri Malang \\ Malang, Indonesia \\ dimas.arif.fip@um.ac.id
}

\begin{abstract}
The social environment in the inclusion school setting is not as we expected because the incident of bullying until persecution still occurs and the targets are students with special needs. The method used in this research is descriptive research with phenomenology approach. The results of the study found two main findings. First, there is lack of preparedness of the institution of inclusive school education so that there is a deep understanding on all components of the institution of the inclusive school organizer. Second, one of the impacts of the components makes the providers of inclusive education in regular schools be incapable in creating a conducive, safe, and comfortable social environment for children with special needs as it will interfere with the children's learning process.
\end{abstract}

Keywords-social environment, inclusive, children with special need

\section{INTRODUCTION}

Inclusion education is currently becoming a solution where education is no longer divided for regular children or children with special needs. The implementation of inclusive education is based on decrees, charter, laws, with a focus on carrying out human rights so that inclusive education is expected not only a trend but a personal awareness of a nation in carrying out the mandate of human rights. In Indonesia, the implementation of inclusive education has been around since the 1980s but in the process of development, it has experienced ups and downs so that it gradually disappears by itself. Around the year 2000, the implementation of inclusive education began to emerge and develop to this day. Inclusive education is education that is friendly for all children, with an education service system that requires children with special needs to study in the closest schools in ordinary classes with friends of their age [1].

Inclusive education in Indonesia is still in the adjustment stage and does not rule out the possibility if the implementation of inclusion needs a lot of support both micro and macro. Changes that view turned out to grow a new concept in service and education of children with special needs. Three kinds of education services for children with special needs from segregation, integration to inclusion were conducted. Reviewing micro support is how parents are able to deliver students with special needs at the school gate of inclusive education providers with full support commitment, and macro support is the readiness of an organizing school in providing full service and facilities and providing a conducive social environment for students with special needs. One indicator of successful learning in inclusive classes is the active participation of all students in the class [2].

A social environment is a place where a community group conducts an interaction and conducts activities together both with each other or their environment. In reality, the social environment in the inclusion school setting does not go according to expectations. Event after the incident starts from bullying to the worst is persecution still occurs and the target is students with special needs who attend inclusive education providers. Bullying is an act both physically and verbally that has the purpose of hurting others while persecution is systematic treatment or mistreatment by individuals or groups in other individuals or groups. The word bullying comes from English, that is, from the word 'bull,' which means bull happy to duck down here and there. In Indonesian, etymologically the word bully means to bully someone who is a weak person. Whereas in terms of terminology according to the definition of bullying is "a desire to hurt. This desire is shown in action, causing someone suffering [3]. This action is carried out directly by someone or a group stronger, irresponsible, usually repeating, and done with feeling happy".

Still remembered in the case of two students with special needs in Sungai Lilin, South Sumatra around 2014, where two students with special needs (mentally disabled) who were in the sixth-grade elementary school were treated verbal bullying (ridiculed using harsh words) and physical bullying (clawed and crushed and undressed). There are still many similar cases but not all of them can be exposed like this. Therefore the author here wants to examine how the social environment of students with special needs in schools implementing inclusive education through descriptive studies with a phenomenological approach. It is expected that the study will be able to contribute to reconstructing a conducive social environment in the school institution for the implementation of inclusive education. Thus the hope in realizing Indonesia as an inclusive education provider is not just a note on a piece of paper and a mere trend.

\section{METHOD}

Research is a series of observations made over a certain period against a phenomenon that requires answers and explanations. According to Sugiyono the research method is the research method is a scientific way to get valid data with the aim of being found, proven, and developed knowledge so that in turn it can be used to understand, solve, and anticipate problems in business [4]. The method in this study uses 
descriptive research with a phenomenological approach. Where the author examines the events in the natural environment (natural settings) and tries to interpret the phenomenon. Qualitative research is a series of structured activities and encompasses a range of study practices to make it easier for participants to emerge and informants facilitating the world of participants and informants. The research perspective used under the aims of this study is phenomenology that studies the Social Environment of Children with Special Needs in Inclusion Schools.

\section{A. Primary Data Source}

There is the main source of information or a principle called the primary data source. The primary data in this study are based on students with special needs, regular students, and parents or guardians of students, which are then grouped into groups of participants. Researchers here are only as information diggers and do not take part as participants. Researchers use snowball techniques in participant searches. Where snowball technique serves as an effort or method in increasing the number of participants through recommendations of participants who have carried out a series of research activities [5]. Based on the goals that have been designed in this study, the researchers decided to use all students with special needs totaling 12 people, as well as 15 regular students and 10 parents of student guardians in the institution.

\section{B. Secondary Data Source}

Secondary data source based on supporting material from primary data sources, in this study secondary data sources are needed. Definition of secondary data is the source of research data obtained through intermediary media or indirectly in the form of books, records, existing evidence, or archives both published and not publicly published. Secondary data is the source of research data obtained by researchers indirectly through intermediary media (obtained and recorded by other parties) [5]. Therefore the author divides into several parts including the informant, written documents, and document not written.

\section{1) Informant}

In gathering supporting data related to the validity of information obtained by researchers from other informants (significant others) who are able to account for all the information, we called it the informant. In this study, the subject (significant others) is the attitude of educators and education staff and the school committee where according to the researchers, they have known and understood the situation in the institution very well.

\section{2) Written documents}

According to Sugiyono, documents can be classified into several forms, such as hand-writing, pictures, and writing form such as diaries, life histories, stories, biographies, regulations, policies, and others, picture forms, like photos, live pictures, sketches and, films, and other. Moreover, written documents, the researcher intends to collect data related to the number of students with special needs as well as the overall number of students who do education in the institution [5].

\section{3) Document not written}

The unwritten document in this study is a record of the condition of participants related to physical and mental conditions in which researchers need these records to determine the readiness of participants in a series of research activities.

\section{Data Collection Technique}

\section{1) Interview}

The interview is a method of data collection strategy by conducting dialogues directly with data sources, which should be carried out according to the procedure and systematic steps, and consciously the participants have freedom and the opportunity to express all ideas or thoughts naturally without a fictional thought from participants. Openended questions are asked to participants to give detailed answers to what they want to say, open-ended questions will ease the dialogue process and help participants describe their experiences obviously without any engineering elements..

\section{2) Observation}

Observations are carried out by researchers in order to obtain direct observations of the pattern of conditions related to the theme of the social environment. Observation is a data collection technique, where researchers make observations directly to the object of research to look closely at the activities carried out [6]. Observations in this study are based on instrument instruments in the form of; 1) anecdotal records, namely matters pertaining to the results of the notes in the field at the time of the research activity which contains a description of social environmental phenomena that are not in accordance with the norm, and 2) a three-scale rating scale (never, rarely, ever) to observe the quality of the symptoms of the social environment phenomenon in the school that was raised.

\section{3) Documents}

One type of data in qualitative research is written material, such as passages and whole documents, correspondence, recordings, and historical cases. Documentation is used for research purposes because; 1) functioning as a stable and supportive source, 2) functioning as evidence for a test, 3) having a natural nature because it suits with the context, born and in context and, 4) the results of the content assessment will expand knowledge of something investigated. The documentation method in this study is used to collect data on the number of students with special needs and the total number of students in the school institution.

\section{Credibility}

The credibility in this study was carried out in the form; 1) carefully record findings in the field; 2) arrange the findings completely and regularly; 3) member check, which is by asking participants to reread the findings recorded and signed; 4) peer checking, in the form of checking interview results, observation with peers through discussion; 5) data triangulation, in the form of checking the validity of data through other sources, namely; written documents, schools and related agencies; 5) adequacy of references, namely; as a tool that can help researchers in the field and as an evaluation tool in the preparation of research results [7]. 


\section{RESULT AND DISCUSSION}

The study found various findings that refer to the title of the phenomenon of the social life of children with special needs in inclusive schools. In mapping the results of the research, the researcher began with a brief exposure to the findings found during the interview. Findings found by the authors include: (1) $60 \%$ of students with special needs received bullying treatment, (2) $80 \%$ of parents of regular students did not understand children with special needs, (3) $75 \%$ of the school environment component could not accept the presence of children with special needs and (4) $90 \%$ argue with readiness for students with needs special.

The numbers are quite significant with a fairly basic reason in a revitalization in the implementation of an inclusive education. Some fundamental reasons related to the understanding of children with special needs lead to social impacts, namely their acceptance (children with special needs) in the social environment in inclusive schools. This ignorance is also coupled with the unilateral perception of all members of the school environment that organizes inclusive education. As well as the results of interviews from 3 parents of regular students, we can translate it as follows (1) the parents of regular students assumed that children with special needs are a disease that could be contagious at any time and (2) parents assumed that their school accepted children with special needs are the same as their children (parents of students) attending school extraordinary.

In addition to the results of interviews from the parents, the researchers obtained the results of interviews from the teacher and education staff in a sampling manner. The researchers concluded from 3 interviews as sampling results and obtained the following results: (1) teachers feel unable to provide maximum learning to students with special needs, (2) do not have special staff who understand and can serve students with special needs or lack of teachers from the field of special education, and (3) teachers feel burdened and disturbed during the process of teaching and learning takes place.

The implementation of inclusive education is not as easy as turning the palm of the hand. However, findings in the field that refer to implementation are not in accordance with administration. The expectation of legislation with field events as if inversely 360 degrees is very inappropriate.

Infrastructure support is also a problem that will continue to go with the journey of inclusive education in Indonesia. In addition to physical support, this process needs to be supported also by non-physical, in this case, the school environment (teachers, parents, school heads, and educators) [8]. Parents of children with special needs have a big role, both in decision-making for education and to support their children [9]. Parental support is the involvement of parents in a variety of forms including care in the home, creating a safe and stable situation, and the right care model [10]. A child with special needs can reach his potential to the fullest if he has full support from his parents. Support from the mother can bring valuable feelings to the child, while support from the father can develop children's competence [8].
To increase people's awareness parents and the community are required to participate in schools and related regional officials. For example a school in collaboration with the driving team to socialize the presence of children with special needs and inclusive school. This collaboration is expected to be able to foster public awareness of the lowest layer.

Helping parents of regular students in understanding the concept of children with special needs is at the translation level, while for the type or classification of children with special needs and their impact is not yet on the level of translation. Parents' understanding of regular students about the implementation and implementation of inclusive education, learning together with children special needs in inclusive settings is not yet at the level of translation or high understanding. Parents' regular understanding of concepts, philosophies, and policies related to inclusive education is not at the level of translation.

Limited knowledge and understanding of parents of regular students about the concept of children with special needs, their children learn together with children with special needs, and the concept of inclusive education, in part because of the lack of prior knowledge received [11]. Therefore, universities in certain majors or special education programs must be able to improve or optimize the provision of counseling or seminars that address inclusive education and children with special needs in inclusive schools [12, $13]$.

Considering that the expectations suggested by the researchers in this study are accompanied by a number of practical considerations, that is given the importance of increasing the knowledge and understanding of teachers and education staff about the implementation of inclusive education and children with special needs is essential and will be realized if competent institutions, especially development centers carry out or make plans for education and training activities in the field of special education inclusion arrangements.

The results of the study found two main evidence. First, they are lack of preparedness of the institution of inclusive school education so that there is a deep understanding on all components of the institution of the inclusive school organizer. Secondly, one of the impacts of the components causes the providers of inclusive education in regular schools to be incapable of creating a conducive, safe, and comfortable social environment for children with special needs as it will interfere with the child's learning process. Therefore it is important to hold an in-depth socialization step towards all components of the social environment at the children's learning places with special needs.

Besides that, an effort is needed from the central government to promote the existence of inclusive schools and positive impacts to be obtained. During the 10 years of implementation of inclusive education, the government just gives assistance in the financial sector, but they have not promoted it yet. 


\section{CONCLUSION}

Based on the description above, the researcher concludes that the school environment has a significant impact on the process of implementing inclusive education. Therefore it is very necessary to improve competence both in terms of theoretical understanding and practical experience. The improvement efforts are expected to be able to encourage the implementation of conducive inclusive education and be able to protect all students with special needs in inclusive schools.

\section{REFERENCES}

[1] N. I. Herawati, Pendidikan Inklusif. EDUHUMANIORA: Jurnal Pendidikan Dasar, 2016. 2(1)

[2] E. Iarskaia-Smirnova and P. Romanov. Perspectives of inclusive education in Russia. European Journal of Social Work, 2007, 10.1: 89-105.

[3] E. W. Ross. Becoming a teacher: The development of preservice teacher perspectives. Action in Teacher Education, 1988, 10.2: 101109.

[4] K. M. Jones-Goods, Grant, Marquis Carter. A phenomenologica study of cultural responsiveness in special education. Journal of Research Initiatives, 2016, 2.1: 17.
[5] P. Sugiyono, Memahami Penelitian Kualitatif. Bandung: Alfabeta. 2005

[6] J. W. Creswell, Qualitative inquiry and research design: Choosing among five tradition. 1998.

[7] J. A Smith and M. Osborn. Interpretative phenomenological analysis. Doing social psychology research, 2004, pp.229-254.

[8] S. D. Alborn-Yilek, Phenomenological study of special education teachers using an emergency license. 2010.

[9] N. Praptiningrum, Fenomena penyelenggaraan pendidikan inklusif bagi anak berkebutuhan khusus. JPK: Jurnal Pendidikan Khusus, 2012, 7.2

[10] J. S. Peterson. Gifted and gay: A study of the adolescent experience. Gifted Child Quarterly, 2000, 44.4: 231-246.

[11] J. M. Kauffman and D. P. Hallahan. The illusion of full inclusion: A comprehensive critique of a current special education bandwagon. PRO-ED, Inc., 8700 Shoal Creek Blvd., Austin, TX 78757-6897, 1995

[12] D. Mcghie-Richmond. Teacher perspectives on inclusive education in rural Alberta, Canada. Canadian Journal of Education, 2013, 36.1: 195

[13] D. Rahardja, Understanding of Special Teachers in Teaching Children with Special Needs at Inclusive Schools. Journal of ICSAR, 2017. 1(1), 13-17 